\title{
Jaký efekt mají klimatické kampaně? Využití Metodiky pro hodnocení dopadu klimatických kampaní
}

\author{
Jan Urban, Tomáš Chabada, Jan Skalík \\ Envigogika 12 (2) - Recenzované články/ Reviewed articles
}

Publikováno / Published 28. 12. 2017

DOI : $10.14712 / 18023061.557$

\begin{abstract}
Abstrakt
Cílem tohoto textu je přibližit cíle a využití Metodiky pro hodnocení dopadů klimatických kampaní. Tato Metodika stanovuje rámec pro provádění hodnotících studií, které se zaměřují na hodnocení kauzálního dopadu klimatických kampaní na změnu individuálního mitigačního nebo adaptačního chování, anebo jeho motivačních faktorů (např. postojů, znalostí a představ). Hodnocení kauzálních dopadů vychází z rámce potenciálních výsledků (Rubin, 1974) a je postaveno na kvantitativních experimentálních a kvazi-experimentálních přistupech. Tato Metodika by měla usnadnit vyhodnocování efektů klimatických kampaní a měla by umožnit akumulaci poznatků o efektech různých typů intervencí. Využívání Metodiky při realizaci a hodnocení kampaní by mělo přispět nejen ke zvýšení efektů realizovaných kampaní a tím ke zvýšení efektivity vynaložených prostředků na klimatické kampaně, ale mělo by také zvýšit důvěru donorů a širší veřejnosti v to, že klimatické kampaně jsou efektivními nástroji klimatické politiky. $\vee$ neposlední řadě by představovaná Metodika měla také usnadnit výměnu informací mezi výzkumníky, kteří se zabývají dopady kampaní, ale často nemají možnost získat informace $z$ reálných kampaní a realizátory kampaní, kterým zase často chybí prostředky pro vyhodnocení dopadů kampaní.
\end{abstract}

\section{Klíčová slova}

klimatické kampaně; hodnocení kauzálních dopadů; velikost efektu; klimatická mitigace

\section{Abstract}

The purpose of this paper is to introduce a certified methodology suitable for evaluation of effects of climate change campaigns. This certified methodology sets a framework for evaluation of causal effects of campaigns aiming at a change of individual mitigation or adaptation behavior, or their motivation factors (e.g., attitudes, knowledge, or beliefs). Evaluation of causal effects is based on a potential outcome framework (Rubin, 1974) and makes use of quantitative experimental and quasi-experimental approaches. This certified methodology should facilitate evaluation of campaigns' effects and should also make it easier to accumulate knowledge about effects of specific interventions. Use of this certified methodology should not only lead to an increase in the effect size of new campaigns, and thus to an increase in cost effectiveness of campaigns but it should also increase trust of donors and the public in campaigns as tools of climatic policy. Last but not least, this methodology should also facilitate exchange of information between researchers who study campaigns but have sometimes very limited access to information about existing campaigns, and those who create campaigns, oftentimes without resources to analyze their effects.

\section{Key-words}

climate change campaigns; evaluation of causal effects, effect size; climate mitigation 
Klimatická změna je jedním z nejvážnějších problémů, kterým lidstvo v současnosti čelí (World Economic Forum, 2017). Lidé s velkou pravděpodobností zapříčinili současnou klimatickou změnu (IPCC, 2014) a jsou také zodpovědní za další prohlubování tohoto problému v důsledku zvyšujících se emisí skleníkových plynů (Boden, Andres, \& Marland, 2017).

Někteří odborníci se domnívají, že důležitou, byt́ podceňovanou, roli by $v$ rámci mitigačních strategií měly hrát př́stupy, které se zaměřují na změnu každodenního chování, zejména dopravního chování a spotřeby energií a potravin (Vandenbergh, Barkenbus, \& Gilligan, 2008). Změna každodenního chování by totiž měla být poměrně rychlá a levná a teoreticky by mohla přinést relativně rychlé snížení emisí skleníkových plynů, které by vytvořilo časový prostor pro hledání účinnějších strukturních opatření.

Významnou roli při změně chování jednotlivců mohou hrát kampaně zaměřené bud'na změnu individuálního chování, anebo na změnu faktorů, které takové chování ovlivňují. Takové kampaně mohou mít za cíl bud' změnu samotného mitigačního chování jednotlivců nebo individuální podporu kolektivním mitigačním opatřením, anebo mohou usilovat o změnu motivačních faktorů (postojů, znalostí, představ), které následně vyvolají i změnu chování.

Jak si však můžeme být jisti, že kampaně mají zamýšlený efekt? Jak je možné tento efekt měřit a jak je možné efekt těchto kampaní správně interpretovat? Na tyto otázky dává odpověd' Metodika, kterou jsme vytvořili a kterou nyní stručně představíme (Metodika je dostupná v repozitáŕi na adrese: https://osf.io/d82qx/).

\section{Cíle Metodiky}

Cílem Metodiky pro hodnocení dopadu klimatických kampaní je poskytnout referenční rámec pro hodnocení kauzálních dopadů klimatických kampaní, tedy kampaní usilujících o změnu individuálního chování zaměřeného na mitigaci a adaptaci vǔči projevům změny klimatu (dále označovaného zkráceně jako mitigační a adaptační chování), anebo o změnu faktorů motivace (jako např. postojů, znalostí, nebo představ), které mohou k takové změně chování vést. Tato Metodika představuje jednak postupy, které slouží k hodnocení kauzálních dopadů kampaní, a jednak kritéria, která umožňují hodnotit velikost kauzálních dopadů kampaní a správně je interpretovat.

Hodnocení kauzálních dopadů klimatických kampaní je možné realizovat pouze s využitím kvantitativních experimentálních a kvaziexperimentálních metod (viz např. Chatterji, 2016; Orr, 1998). Užívané postupy se však liší od obecně známých nástrojů používaných pro evaluace programů a projektů, kde se obvykle hodnotí jiné aspekty než kauzální dopady a kromě kvantitativních metod využívají i jiné postupy hodnocení, které však nejsou pro hodnocené kauzálních dopadů relevantní (aktuální přehled těchto široce pojatých evaluačních metod uvádí např. Stufflebeam \& Coryn, 2014). Předkládaná Metodika se také odlišuje od stávající metodiky pro hodnocení environmentálního vzdělávání (Činčera, 2010, 2013a, 2013b), která se sice také zaměřuje na zkoumání kauzálních dopadů, ale se zaměřením na dopady environmentálního vzdělávání. Liší se i od jiných metodik, jejichž cílem je hodnocení jiných aspektů projektů než kauzálních dopadů, jako například hodnocení projektového cyklu (Ministerstvo pro místní rozvoj, 2016; Potulka \& Špaček, 2013).

Hodnocení kauzálních dopadů má v kontextu klimatických kampaní mimořádnou důležitost, protože potenciální prínos dobře fungujících kampaní je velký a velké mohou poten- 
ciálně být i finanční náklady spojené s realizací takových kampaní. Takové hodnocení umožňuje předkládaná Metodika, která by $z$ dlouhodobého hlediska měla přispět $k$ tomu, aby kampaně využívaly co nejúčinnější prostředky a dosahovaly co největší změny chování.

\section{Pro jaké typy kampaní je Metodika vhodná}

Metodika pro hodnocení dopadu klimatických kampaní představuje celé spektrum různých př́stupů k hodnocení kauzálních dopadů kampaní. To ale neznamená, že všechny tyto přistupy jsou vhodné pro všechny typy kampaní. Metodika stanovuje dva základní principy, které by měly pomoci s výběrem vhodného postupu hodnocení.

\subsection{Pravidlo přiměřenosti}

Základním pravidlem pro hodnocení kampaně je pravidlo přiměřenosti: finanční a odborná náročnost hodnocení kampaně by měla odpovídat nákladům kampaně a důvodům její realizace. V Metodice přestavujeme tři úrovně hodnocení kauzálního efektu kampaní a uvádíme orientační informace o finanční a odborné náročnosti těchto přistupů. Obecně platí, že čím přesnější informace může určitý způsob hodnocení poskytnout o kauzálních dopadech kampaní, tím vyšší bude jeho finanční a odborná náročnost. Nyní tyto tři úrovně hodnocení krátce shrneme.

Orientační hodnocení je nejjednodušší a nejméně náročný (z finančního a odborného hlediska) způsob hodnocení dopadů kampaní. Toto hodnocení není založeno na vlastním výzkumu, ale využívá přehledy nebo metaanalýzy existujících studií, které zkoumaly kauzální efekty stejných nebo typově podobných kampaní. Toto hodnocení dává odpověd' na otázku, jestli stejný (nebo podobný) typ kampaně může vůbec vyvolat kauzální efekty, které jsou v kampani plánovány, a jak velké tyto efekty mohou být. Takové hodnocení je orientační a v některých případech ho nebude možné provést (např. pokud neexistují studie, které by typově podobné kampaně zkoumaly). Nicméně i takové orientační hodnocení je užitečné $\checkmark$ jakékoli fázi př́pravy a realizaci kampaně, protože umožňuje zvolit optimální strategii pro realizaci kampaně a do budoucna vytváŕí podmínky pro to, aby byly skutečné dopady takové kampaně lépe prostudovány a prakticky využivány. Řádově se náklady u tohoto typu hodnocení budou pohybovat přibližně v intervalu 40-80 tis. Kč.

Základní hodnocení je vyšší úrovní hodnocení dopadů a je založeno na vlastním výzkumu, tedy sběru dat o dopadech prováděné kampaně. Základní hodnocení však využívá zjednodušené postupy (laboratorní experimenty, webové experimenty, šetření), které dávají odpověd' na otázku, jestli konkrétní postupy využité v kampani mají, za ideálních podmínek, očekávané dopady a jak velké tyto dopady jsou. Tento typ hodnocení pravděpodobně bude muset realizovat odborník, který má zkušenosti s využitím kvantitativních výzkumných metod. Náklady tohoto typu hodnocení se budou pohybovat v intervalu 80-300 tis. Kč.

Pokročilé hodnocení je nejvyšším stupněm hodnocení dopadů, a ačkoli může používat podobné postupy jako základní hodnocení, bude se od něj lišit tím, že se snaží odpovědět na otázku, jestli realizovaná kampaň skutečně měla zamýšlené kauzální dopady a jak velký dopad kampaně byl. Pokročilé hodnocení bude mít často podobu field experimentu, anebo bude realizováno jiným způsobem př́mo na cílové skupině kampaně. Pokročilé hodnocení bude mít obvykle vysokou statistickou sílu a výsledky tohoto hodnocení budou platné i za přijetí slabších předpokladů, než základní hodnocení. Tím pádem budou výsledky takového hodnocení považovány za prokazatelnější a jistější. Náklady na tento typ hodnocení se budou pohybovat v řádech stovek tisíců Kč. 
U malých kampaní, jejichž náklady na realizaci se pohybují na úrovni několika set tisíc korun, nemá obvykle smysl provádět náročné evaluace, jejichž náklady by dosahovaly podobné výše. $V$ takových př́padech je ale vhodné provést alespoň orientační nebo základní evaluace, které stále mohou přinést důležité informace o dopadech takových kampaní. Vyšší nároky (a tím i zvýšené výdaje) na evaluace malých kampaní ale mohou být oprávněné $\checkmark$ prípadech, kdy by se jednalo o pilotní projekty, jejichž výsledky by rozhodovaly o realizaci větších a nákladnějších kampaní.

Naopak u velkých kampaní, jejichž náklady by se pohybovaly na úrovni miliónů či desítek milionů korun na jednu kampaň, je provedení pokročilých evaluací vhodné. Takové evaluace dávají přesnější informace o dopadech kampaně a jsou důležitým podkladem pro rozhodování o tom, jestli podobné kampaň realizovat v budoucnosti a za jakých podmínek.

Jako základní vodítko doporučujeme pro přiměřenost nákladů hodnocení kampaní rozmezí 3\%-15\% nákladů samotné kampaně. Jinými slovy, pro kampaň, jejíz náklady se budou pohybovat na úrovní 400000 Kč, by se očekávané náklady na evaluaci měly pohybovat mezi 12 a 60 tis. Kč. Takové prostředky umožňuji maximálně provedení orientační evaluace, která je založena na rešerši dostupných studií a nebude zahrnovat vlastní výzkum. U kampaní s menším rozpočtem je při zachování pravidla přiměřenosti provedení hodnocení kauzálních dopadů obtížné. Naopak u kampaně, jejiž náklady se budou pohybovat na úrovni 2 mil. Kč a přiměřené náklady na evaluaci se u ní budou pohybovat mezi 60 a 300 tis. Kč, by již měla být provedena minimálně základní nebo dokonce pokročilá evaluace dopadů kampaně.

\subsection{Pravidlo prokazatelnosti kauzálních efektů}

Metodika pro hodnocení dopadu klimatických kampaní je založena na statistickém rámci pro hodnocení kauzálních dopadů vycházejícího z Rubinova modelu potenciálních výsledků (Rubin, 1974) a je postavena na využití standardizovaných kvantitativních metod. Takový rámec je vhodný v prípadech, kdy může být evaluace postavena na pozorování minimálně desítek nebo spíše stovek jednotlivců a současně mohou být tato pozorování prováděna standardizovaným způsobem (tj. bude se jednat o standardizovaná pozorování). ${ }^{1}$ Ve většině případů využívá hodnocení kauzálních dopadů postupy statistické indukce: hodnocení je prováděno na vzorku a výsledky hodnocení se zobecňují na populaci, z níž vzorek pochází. $V$ těchto prípadech by měly být zajištěny podmínky pro použití statistické indukce (tj. např́klad náhodný výběr vzorku z populace, anebo alespoň výběr, který dovede aproximovat vlastnosti náhodného výběru, např. kvótní výběr).

U menších vzorků recipientů kampaní nebude tato Metodika vhodná z toho prostého důvodu, že metody, které využívá (statistickou indukci) budou mít př́liš malou statistickou sílu a tedy nebudou moci prokázat efekty kampaní, i kdyby skutečně existovaly. $\vee$ prípadech, kdy nebude možné pozorování standardizovat, bude docházet k podobnému problému: získaná pozorování budou zatížena velkou chybou měření anebo velkou systematickou chybou, což může mít za následek opět to, že evaluace nebude schopna efekt prokázat, i kdyby reálně existoval.

\footnotetext{
${ }^{1}$ Standardizovaná pozorování jsou taková pozorování, která jsou formalizována. Typickým př́kladem standardizovaného pozorování je šetření s využitím dotazníku. Protože mají taková pozorování podobnou formální strukturu, je možné je snadno překódovat do formátu číselných dat a dále je analyzovat s využitím metod statistického usuzování.
} 
Typickými př́klady kampaní, pro které není tato Metodika hodnocení vhodná, jsou kampaně zaměřené na různé vlivové skupiny (poslance, podnikatele, skupiny opinion leaderů). Takové skupiny budou často velmi malé, anebo nebude technicky možné získat u těchto skupin standardizovaná pozorování (např. odpovědi na dotazník), při zajištění dostatečné reprezentativity. Tato Metodika naopak bude vhodná v případech, kdy kampaně cílí na relativně velkou skupinu př́jemců (obyvatelé ČR nebo nějaké oblasti, žáci nebo studenti, určitá socioprofesní nebo věková skupina apod.).

\section{Pro koho je Metodika určena}

Tato Metodika je určena primárně jako metodické vodítko pro odborníky, kteří budou provádět hodnocení dopadů kampaní, a pro oponenty, kteří mohou kvalitu takových evaluací posuzovat. Sekundárně je tato Metodika určena i pro zadavatele hodnocení (což často budou donoři finančních prostředků) i pro realizátory klimatických kampaní. Nyní stručně shrneme, co každá z těchto skupin uživatelů může od Metodiky očekávat.

\subsection{Odborníci provádějící hodnocení dopadů kampaní}

Odborníci provádějící hodnocení dopadů kampaní najdou v metodice rámcová pravidla pro provádění hodnocení, nástroje na provádění evaluací (škály k měření konstruktů), minimální standardy hodnocení, praktické ukázky různých přístupů k hodnocení kampaní (v podobě demonstračních studií) a odkazy na další literaturu. Metodika je psána právě pro tuto skupinu uživatelů a je psána jazykem, který by měl být pro tuto skupinu srozumitelný a současně by měl být jednoznačný.

Metodika by neměla být chápána jako autoritativní dokument, který taxativně stanovuje přijatelné postupy hodnocení, ale spíše jako vodítko pro výběr a aplikaci obecně přijímaných metodologických postupů (např. různých typů experimentálních a kvaziexperimentálních výzkumných uspořádání), které jsou vhodné i pro hodnocení dopadů. Rádi bychom hodnotitele pobídli, aby sami dokumentovali prováděné evaluace (např. formou článkư nebo zpráv) a sdíleli je s ostatními, nebo navrhovali lepší metodologická řešení, než jaká jsou popsána $v$ této Metodice. Takové poznatky budou užitečné při budoucích aktualizacích této Metodiky a jako podpora práce ostatních evaluátorů.

\subsection{Hodnotitelé evaluací}

Hodnotitelé evaluací (odborní oponenti evaluačních zpráv) představují druhou skupinu uživatelů, pro něž byla tato metodika připravena. Hodnotitelé evaluací by v této metodice měli především nalézt minimální požadované standardy pro hodnocení kauzálních dopadů kampaní. Pomocí těchto kritérii budou moci posoudit, jestli evaluační studie dosahují potřebné kvality vzhledem k povaze samotných kampaní. Jazyk této Metodiky by měl být odborným oponentům snadno srozumitelný.

\subsection{Zadavatelé hodnotící zpráv}

Zadavatelé hodnotících zpráv, at' už to jsou donoři, anebo sami realizátoři kampaní, si mohou na základě této Metodiky vytvořit rámcovou představu o tom, jaké jsou možné typy evaluací, na jaké otázky odpovídají a jaká je odborná a finanční náročnost je s nimi spojena. Na základě takových informací se mohou zadavatelé hodnotících zpráv rozhodnout, jak přesnou informaci o dopadech kampaní potřebují, a tomu přizpůsobit požadavky na kvalitu evaluačních studií. Nároky na kvalitu evaluační studie se následně mohou promítnout do všech fází realizace projektu od zadání projektové výzvy, přes hodnocení návrhů projektů, hodnocení průběhu projektu, až po závěrečné hodnocení výsledků projektů. 
Pro zadavatele hodnotících zpráv by měla být srozumitelná rámcová pravidla a doporučení popsaná $v$ této Metodice, ale je pravděpodobné, že některé technické podrobnosti evaluací jim mohu být méně srozumitelné.

\subsection{Realizátoři kampaní}

Realizátoři kampaní v této Metodice naleznou rámcová pravidla pro hodnocení kampaní $\vee$ závislosti na jejich rozsahu. Podstatné je přitom pravidlo přiměřenosti zmiňované výše a podrobněji v Kapitole 5 Metodiky. Vzhledem k různým kategoriím velikosti kampaní jsou v Metodice uvedeny příklady provedených hodnocení. Tyto informace by měly pomoci realizátorům při plánování kampaně a eventuálně i její evaluace. Realizátoři kampaní by také mohli být schopni na základě metodických doporučení obsažených v této Metodice realizovat jednoduché orientační evaluace dopadů kampaně (formou rešerše předchozích evaluačních studií) a měli by být schopni formulovat rámcové zadání pro externí evaluaci $v$ případě, kdy mají být použity náročnější evaluační postupy.

Tato Metodika nepředpokládá, že by složitější evaluace prováděli sami realizátoři kampaní, i když i takový postup je možný. Z tohoto důvodu není tato Metodika detailním návodem, jak přesně evaluaci kauzálních dopadů provádět, ale je spíše přehledem postupů, které by měly být při hodnocení kauzálních dopadů používány. Pro realizátory kampaní by proto měla být srozumitelná rámcová pravidla a doporučení popsaná $v$ této Metodice, ale je pravděpodobné, že některé technické podrobnosti evaluací pro ně mohou být méně srozumitelné.

\section{4. Členění Metodiky}

Metodika pro hodnocení dopadu klimatických kampaní je členěna do pěti kapitol. Každá kapitola se zabývá samostatným tématem souvisejícím s př́pravou a realizací hodnotících studií. $V$ závěru každé kapitoly je uvedeno shrnutí kapitoly a je zde navržena základní rozšiřující literatura (tř̌i hlavní zdroje) a dále kompletní seznam textů, které jsou v příslušné kapitole citovány. Kromě jednotlivých kapitol zahrnuje Metodika i př́lohy, které podrobněji popisují využité nástroje hodbnocení.

Ve druhé kapitole, následující po úvodu, jsou popsány základní indikátory dopadů klimatických kampaní. Pomocí těchto indikátorů je možné měřit to, co má klimatická kampaň dosahovat, at' už je to změna postojů, znalostí, nebo představ o změně klimatu, anebo změna chování souvisejícího $s$ klimatickou změnou, tj. bud' mitigačního nebo adaptačního chování. Součástí této kapitoly je i několik příloh, které obsahují používané nástroje pro evaluaci dopadů klimatických kampaní.

Třetí kapitola Metodiky popisuje různé způsoby odhadu kauzálního efektu, které vycházejí $z$ teoretického rámce očekávaných výsledků. Tento rámec je běžně využíván $v$ aplikované statistice pro odhad kauzálních efektů. Tato kapitola popisuje využívání různých experimentálních a kvaziexperimentálních přístupů při zkoumání kauzálního dopadu a výhody a omezení těchto př́stupů.

Čtvrtá kapitola pojednává o posuzování naměřeného kauzálního efektu a interpretaci jeho velikosti. Tato kapitola také upozorňuje na některá úskalí hodnocení velikosti efektu, zejména na fakt, že takové hodnocení je vždy nutné interpretovat v kontextu efektů naměřených $v$ podobné oblasti, a také upozorňuje na rozdíly mezi statistickou a praktickou významností určitého efektu. 
Pátá kapitola Metodiky představuje tři úrovně evaluace: orientační, základní a pokročilou evaluaci. Tyto tři úrovně se liší jednak svými nároky (finančními, odbornými a jinými), ale také kvalitou hodnocení kauzálních dopadů. Obecně platí, že vyšší kvalita evaluace je spojena s vyšší náročností evaluace. Jednotlivé úrovně hodnocení jsou přiblíženy na príkladu demonstračních studií, které v minulosti hodnotily dopady konkrétních kampaní. V této kapitole uvádíme také orientační náklady jednotlivých úrovní evaluace a navrhujeme orientační pravidlo přiměřenosti, které stanovuje, že náklady realizace evaluační studie by měly odpovídat $3 \%-15 \%$ nákladů kampaně.

Konečně šestá kapitola Metodiky se zabývá výběrem realizátorů hodnotících studií. Tato kapitola upozorňuje na fakt, že ve většině prípadů budou evaluace provádět externisté, jednotlivci nebo organizace, kteří se nepodíleli na realizaci kampaně. Evaluátory tak budou většinou bud' specializovaní odborní hodnotitelé, anebo specialisté se širším profesním zaměřením, jako např. kvantitativní výzkumníci. Interní evaluace kampaní, tedy evaluace prováděné samotnými realizátory kampaní, jsou pravděpodobné v př́padech, kdy rizika vyplývající ze střetu zájmů jsou relativně malá a kdy jsou realizátoři odborně schopní evaluace zpracovat (což bude často př́pad orientačních evaluací).

Přílohy, které jsou součástí Metodiky, dokumentují škály využívané při měření postojů ke klimatické změně, a způsoby měření znalostí mechanismu klimatické změny a měření mitigačního chování pomocí informací uváděných respondenty nebo pomocí kalkulačky individuální uhlíkové stopy.

\section{Závěr}

Metodika pro hodnocení dopadu klimatických kampaní nabízí rámec pro analýzu kauzálních dopadů klimatických kampaní a pro správnou interpretaci těchto efektů. Tato Metodika by měla usnadnit vyhodnocování dopadů klimatických kampaní a měla by umožnit akumulaci poznatků o efektech různých typů intervencí. Využívání Metodiky při realizaci a hodnocení kampaní by mělo přispět nejen ke zvýšení efektů realizovaných kampaní a tím ke zvýšení efektivity vynaložených prostředků na klimatické kampaně, ale mělo by také zvýšit důvěru donorů a širši veřejnosti $v$ to, že klimatické kampaně jsou účinnými nástroji klimatické politiky. Naším přáním je, aby tato Metodika usnadnila také výměnu informací mezi výzkumníky, kteři se zabývají dopady kampaní, ale často nemají možnost získat informace z reálných kampaní, a realizátory kampaní, kterým zase často chybí prostředky pro vyhodnocení dopadů kampaní.

\section{Poděkování}

Vznik tohoto textu i Metodiky pro hodnocení dopadů klimatických kampaní, kterou v tomto textu představujeme, byl podpořen $v$ rámci projektu TAČR "Nástroje pro hodnocení dopadu kampaní zaměřených na snížení individuálních emisí skleníkových plynů", č. TD03000282. Další výstupy $\mathrm{z}$ tohoto projektu jsou dostupné $v$ repozitáři zde: https://osf.io/tj8fm/ .

\section{Seznam literatury}

- Boden, T., Andres, R., \& Marland, G. (2017). Global, Regional, and National FossilFuel CO2 Emissions (1751 - 2014) (V. 2017). Carbon Dioxide Information Analysis 
Center (CDIAC), Oak Ridge National Laboratory (ORNL), Oak Ridge, TN (United States). , http://dx.doi.org/10.3334/CDIAC/00001_V2017

- Činčera, J. (2010). Metodika evaluace programů environmentální výchovy. Envigogika, 5(3), Retrieved from http://www.envigogika.cuni.cz/index.php/Envigogika/article/view/149 http://dx.doi.org/10.14712/18023061.149

- Činčera, J. (2013a). Metodika pro hodnocení environmentální výchovy pro dospělé účastníky. Envigogika, 8(5), 10-14712. Retrieved from http://www.envigogika.cuni.cz/index.php/Envigogika/article/view/415 http://dx.doi.org/10.14712/18023061.415

- Činčera, J. (2013b). Metodika pro hodnocení environmentální výchovy pro předškolní děti a mladší školní věk. Envigogika, 8(5), 10-14712. Retrieved from http://www.envigogika.cuni.cz/index.php/Envigogika/article/view/413 http://dx.doi.org/10.14712/18023061.413

- Chatterji, M. (2016). Causal inferences on the effectiveness of complex social programs: Navigating assumptions, sources of complexity and evaluation design challenges. Evaluation and Program Planning, 59, 128-140. Retrieved from http://linkinghub.elsevier.com/retrieve/pii/S0149718916301094 http://dx.doi.org/10.1016/j. evalprogplan.2016.05.009

- IPCC (2014). Climate Change 2014: Synthesis Report. Contribution of Working Groups I, II and III to the Fifth Assessment Report of the Intergovernmental Panel on Climate Change. (R. K. Pachauri \& L. Mayer, Ed.). Geneva: IPCC. Retrieved from http://www.ipcc.ch/pdf/assessment-report/ar5/syr/SYR_AR5_FINAL_full.pdf

- Ministerstvo pro místní rozvoj (2016). Metodický pokyn pro evaluace v programovém období 2014 - 2020. Praha: MMR. Retrieved from http://www. dotaceeu.cz/getmedia/9cf7f984-4748-4695-901c-d9b10f12bcd6/MP-evaluace_v4.pdf?ext=.pdf

- Orr, L. L. (1998). Social Experiments: Evaluating Public Programs With Experimental Methods (1. vyd.) : Sage Publications, Inc.

- Potulka, O., \& Špaček, M, (2013). Postupy a metody kontrafaktuálních dopadových evaluací pro Operační program Zaměstnanost v období 2014 - 2020. . Retrieved from https://www.mpsv.cz/files/clanky/17051/Metodika_CIE_MPSV_131015.pdf

- Rubin, D. (1974). Estimating Causal Effects of Treatments in Randomized and Nonrandomized Studies. Journal of Education Psychology, 66(5), 688-701. Retrieved from http://content.apa.org/journals/edu/66/5/688 http://dx.doi.org/10.1037/h0037350

- Stufflebeam, D. L., \& Coryn, C. L. S. (2014). Evaluation theory, models, and applications (Second edition). San Francisco: Jossey-Bass \& Pfeiffer Imprints, Wiley.

- Vandenbergh, M. P., Barkenbus, J., \& Gilligan, J. M. (2008). Individual Carbon Emissions: The Low-Hanging Fruit. UCLA Law Review, 55, 1701-1758.

- World Economic Forum (2017). The Global Risks Report 2017. Retrieved from http://www.deslibris.ca/ID/10090180 